\title{
The experience of a charity in translating the results of basic research to therapies for patients
}

\author{
Lucia Monaco \\ From 7th European Conference on Rare Diseases and Orphan Products (ECRD 2014)
}

Rare diseases represent a relevant societal challenge that calls different players into action, with the aim of providing a diagnosis to patients, understanding the disease pathophysiology and, most importantly, developing treatments and therapies to effectively improve life quality and expectancy.

Biomedical research charities play an important role in the fight against rare diseases, as they are driven by a strong patient need and are focused on diseases otherwise poorly supported by public or private funders. Since 1990, the Telethon Foundation has supported research on genetic diseases, most of which are rare, through intramural and extramural investments in Italy based on strict, excellence-driven fund allocation criteria.

Although Telethon-funded research still relies on a strong base of fundamental studies aimed at disclosing the pathophysiology of genetic diseases, it has progressively shifted towards preclinical and clinical studies, today standing at $50 \%$ of Telethon's investments. In particular, the considerable expertise on gene therapy built at the Telethon Institute for Gene Therapy (TIGET), a joint initiative with the San Raffaele Hospital in Milan, has led to the first safe and effective gene therapy for a genetic disease, the severe immunodeficiency ADASCID [1]. This goal was achieved with continued support by the charity, which included creating a dedicated clinical trial office for regulatory support and training of specialized staff and bearing the cost and risks of the production of the therapeutic vector according to good manufacturing practices.

Finally, making this therapy available to patients required the skills and resources of a pharmaceutical company; dealing with an ultra-rare disease such as ADA-SCID presented a challenge that was met by GlaxoSmithKline (GSK). In 2010, Telethon/San Raffaele

\footnotetext{
Correspondence: Imonaco@telethon.it
}

Fondazione Telethon, Milan, Italy

\section{References}

Scaramuzza S, Andolfi G, Mirolo M, Brigida I, Tabucchi A, Carlucci F, Eibl M, Aker M, Slavin S, Al-Mousa H, Al Ghonaium A, Ferster A, Duppenthaler A, Notarangelo L, Wintergerst U, Buckley RH, Bregni M, Marktel S,

Valsecchi MG, Rossi P, Ciceri F, Miniero R, Bordignon C, Roncarolo MG: Gene therapy for immunodeficiency due to adenosine deaminase deficiency. N Engl J Med 2009, 360:447-58.

2. Biffi A, Montini E, Lorioli L, Cesani M, Fumagalli F, Plati T, Baldoli C, Martino S, Calabria A, Canale S, Benedicenti F, Vallanti G, Biasco L, Leo S, Kabbara N, Zanetti G, Rizzo WB, Mehta NA, Cicalese MP, Casiraghi M, Boelens JJ, Del Carro U, Dow DJ, Schmidt M, Assanelli A, Neduva V, Di Serio C, Stupka E, Gardner J, von Kalle C, Bordignon C, Ciceri F, Rovelli A, Roncarolo MG, Aiuti A, Sessa M, Naldini L: Lentiviral hematopoietic stem cell gene therapy benefits metachromatic leukodystrophy. Science 2013, 341:1233158.

Aiuti A, Biasco L, Scaramuzza S, Ferrua F, Cicalese MP, Baricordi C, Dionisio F, Calabria A, Giannelli S, Castiello MC, Bosticardo M, Evangelio C, Assanelli A, Casiraghi M, Di Nunzio S, Callegaro L, Benati C, Rizzardi P, Pellin D, Di Serio C, Schmidt M, Von Kalle C, Gardner J, Mehta N, Neduva V, Dow DJ, Galy A, Miniero R, Finocchi A, Metin A, Banerjee PP, Orange JS, Galimberti S, Valsecchi MG, Biffi A, Montini E, Villa A, Ciceri F, Roncarolo MG, Naldini L: Lentiviral hematopoietic stem cell gene therapy in patients with Wiskott-Aldrich syndrome. Science 2013, 341:1233151. 
doi:10.1186/1750-1172-9-S1-020

Cite this article as: Monaco: The experience of a charity in translating

the results of basic research to therapies for patients. Orphanet Journal of Rare Diseases 2014 9(Suppl 1):O20.

Submit your next manuscript to BioMed Central and take full advantage of:

- Convenient online submission

- Thorough peer review

- No space constraints or color figure charges

- Immediate publication on acceptance

- Inclusion in PubMed, CAS, Scopus and Google Scholar

- Research which is freely available for redistribution

Submit your manuscript at 